\title{
Analysis of the Development of Carbon Finance in Commercial Banks in Era of Low Carbon Economy
}

\author{
Huiqing Gao, Ming Lei \\ Xi'an International University, Xi'an Shaanxi, 710077, China
}

Keywords: Low carbon economy, Commercial banks, Carbon finance, Development strategy

\begin{abstract}
With the continuous development of social economy, its economic model is developing in low carbon economy, carbon finance has become a new field in the development of banks. As a financial institution, commercial banks should grasp the development opportunity and make it into a new profit growth point.
\end{abstract}

\section{Introduction}

With the continuous development of social economy, environmental and climate change, especially the greenhouse effect of people living environment. In this context, the world bank proposed carbon finance activities. China's banks are mainly based on the clean development mechanism of carbon finance activities. Commercial banks in low-carbon economy era, not only to promote energy-saving emission reduction projects, but also China's carbon trading market to provide protection, improve the low carbon financial market system, to prepare for the world low-carbon economic development.

\section{Overview of low carbon economy and carbon finance}

\section{Low carbon economy.}

Low carbon economy refers to under the concept of continuous development, the use of new energy development, industrial transformation and institutional technology innovation and other methods, reducing the oil coal and other high carbon energy consumption, thereby reducing carbon dioxide gas emissions, promote the ecological environment and social economic development win-win economic form. With the global warming, people's awareness of environmental protection and energy conservation, low-carbon economy development meets the requirements of environmental protection, and become the focus of social development in the world. The concept of low-carbon economy, today's society has formed a low-carbon economy era, and in the low carbon economy era, and promote the formation and development of carbon finance business.

\section{The carbon finance.}

Carbon finance is referring to reduce greenhouse gas emissions, making the financial system and trading activities, carbon finance arise mainly from the Kyoto protocol to the United Nations framework convention on climate change. Under the two international conventions, gradually developed CO2 emissions trading market for sovereignty, and the related financial needs arise. Carbon financial activities including carbon trading, futures and options market for carbon emissions, the carbon finance business such as risk investment and commercial Banks, among them, carbon trading and quotas would be included with the project type two trades, trading of project for secondary CDM and JI, ET carbon trading quotas for the international emissions trading mechanism, and the CDM is the only mechanism associated with developing countries, at present our country's carbon finance is based on CDM project emission reductions and investing and financing transactions, also contain some financial intermediary services. 


\section{The importance of commercial banks develop carbon finance}

\section{Which can promote the rapid development of China's economy.}

In the low carbon economy era, the financial institution is an important driving force, the low carbon economy is still in the primary stage, the need for human, material, financial and technical support, in this case, strengthen commercial banks in low carbon economic support is particularly important, China's commercial banks need to develop the CDM project, in order to promote China's CDM project development, to achieve a short period of economic growth and long-term economic development mode change. At the same time, with the development of low carbon economy, the development of the real economy, the energy, wind and solar energy and other CDM projects have promoted the development of new energy industry in China, and also in the form of economic development.

To promote the development of China's commercial banks.

The development of carbon finance provides a new opportunity for commercial banks, which is a commercial bank in the CDM project. Through financial advisers, financial leasing, fund custodian and fund management, it can effectively expand the income of banks, optimize the bank's profit structure, and carbon finance is a new business, which can effectively promote the commercial banks, such as small and medium enterprises.

To promote the cooperation between commercial banks and international banks in China.

General CDM project requires two or more national commercial banks to cooperate with each other, this can effectively improve China's commercial banks to participate in international business negotiation, international business experience, for the low carbon economy era, the equator principle is not legal effect, can be used as international projects in the international practice and industry standards, to strengthen the low-carbon economy development, and to promote commercial banks to participate in international business.

\section{The development of carbon finance in China's commercial banks} large.

The congnition degree of carbon finance is not enough and the risk of financial business is

China's carbon finance application time is short,caused that the banks have not very knowleage of the carbon deposits business opportunities.And commercial banks are not familiar with the project development, risk management, operation mode and trading rules . The degree of intervention is too shallow, the financial business is concentrated in the low added value and industry downstream, the financial business itself is also facing great risks, including credit, policy and legal risk. The enterprises are faced with price and technology risk, and lack of security during the industry structure from high carbon to low carbon process. Compensation and tax reduction policies, increase the cost of the enterprise, reduce the profitability, which will lead to bank credit risk, bank carbon finance business is also facing policy risks, according to the international Convention, this year, China's commercial banks have a great impact on carbon finance development.

The intermediary market is not perfect, the lack of professional talents.

International carbon finance market, the carbon trading based project development procedures, rules and risk characteristics, the general risk assessment agencies do not have the project evaluation and development capabilities, some intermediaries to obtain their own interests, often to provide false information, virtually increased carbon financial transaction costs, and therefore, China has strengthened the agency, and the construction of third party approved agencies, these agencies are still in the initial stage, the lack of professional and technical advisory body is not perfect, which slows the commercial banks to carry out carbon finance. Carbon finance business has a high demand for talent, and carbon finance is a new industry, the theory knowledge is not perfect, and carbon finance professionals need professional knowledge, such as finance, chemical industry, foreign language and law. 


\section{The lack of trading platform and incentive mechanism.}

China's lack of carbon finance legal system, making China's carbon trading market lack of legal system, lack of legal protection, dissolution of low-carbon economic development needs the government to promote industrial development, can effectively promote industrial development, can effectively promote industrial development, the government is not clear, such as security, risk compensation and tax cut policy is not clear, the financial guidance is not played, the legal environment is not good, these problems slow down the development of commercial banks.

\section{Development strategy of commercial bank carbon finance}

\section{To strengthen the understanding of carbon finance, and expand the carbon finance development business.}

China's commercial banks should change their ideas, strengthen the understanding of carbon finance development, especially the development of carbon finance, improve the operation mode of commercial banks and the international competitiveness and low carbon economy development. At the same time, the development of carbon finance, need to strengthen the development of green credit, energy conservation projects, and implement the environmental protection, high pollution and high energy consumption industries limit line of credit, two is to strengthen low-carbon investment products and related services, which is the term investment value products, carbon securities, carbon futures and funds, etc., three is to provide financial services to enterprises, investment and financing.

\section{Strengthen the cultivation of professional talents.}

Compared with the original business of financial institutions, carbon finance operation mode and derivative products difference greatly. Developing carbon finance business need to be familiar with the relevant international standards, management and operation methods such as, and implement a system for training and learning, but also to establish a team of professionals, carbon finance business to have financial, economic, foreign language, chemical and mathematical statistics knowledge, in a short period of time, cultivate compound talents is unable to realize, which requires take please come in out of the way, through the incentive mechanism to introduce the comprehensive quality talent, and the organization of the original business personnel to participate in training - related business, to meet the needs of carbon finance business and low carbon economic development.

Control of carbon finance business risks and enhance the intermediary business innovation.

Commercial Banks face the carbon finance business credit, policy and legal risk, need to take the following measures to control, one is to control credit risk, commercial Banks in China should choose good project economic benefit, and international financial companies, the world bank and Asian development bank and other financial institutions to strengthen environmental protection project funding support, our country's commercial bank credit risk with international financial organizations; Two is risk control policy, China's commercial Banks should focus on the related carbon emissions international negotiations and financial laws and regulations, try to be ahead of prevention, and actively respond to; Three is the legal risk control, formulate relevant carbon financial contracts, commercial Banks should be hired or consulting at international law the lawyer's office, use is beneficial to the application of law of commercial Banks. For intermediary business innovation from the following measures to perfect, is a priority to the development and the associated carbon trading products, using our country commercial bank investment scope, the size of the market and the advantages of the product category, deepen the development related to carbon trading products; 2 it is to encourage Banks to project financing, strengthen the financing model to explore the CDM project, low-carbon financing mode in our country is still in the test and demonstration stage, no can draw lessons from experience and specification; Three is to strengthen the financial consultants, carbon trading agent and financing guarantee the development of the intermediary business, the commercial Banks in the process of carbon finance, implementing guarantee ratio, and with the project further reducing collateral ratio, commercial Banks should develop CDM consulting, provide enterprises with early on CDM project evaluation to the service of the final transaction receipts; Four is to strengthen the branch of marketing resources, and find out target customer to fit the development of 
CDM projects, with the help of a commercial bank internal professionals to organizations involved in the whole process of project, so as to promote the development of carbon financial business of commercial Banks in China.

\section{Improve relevant laws and regulations, strengthen international cooperation.}

The basic premise for the development of carbon finance, especially the carbon trading market, is a new market, which has a long-term and transparent legal regulations. The government has to consider the carbon finance factor, and to strengthen our country's carbon finance scientific and regulatory standards, and promote the development of carbon finance. China is a developing country, without emission reduction obligations, without the addition of emissions trading, EUETS and CDM and other market trading rules, not exclusion of developing countries to participate in the senior market transactions, commercial banks can through their own channels and network information products too, and have experience in international business and investment bank to form alliances and strategic cooperation, so that our commercial banks can not only get financial support, but also learn from international advanced experience, and promote the development of carbon finance in china.

\section{To strengthen the construction of low-carbon culture.}

The Commercial Bank of our country should put the low carbon culture into the enterprise culture, so that commercial banks have good construction of low carbon economy atmosphere, which requires banks to implement low carbon emission reduction method to daily bank management, save resources, improve the utilization rate, reduce the consumption of resources, the use of telephone and video instead of some travel activities, carry out monthly the carbon footprint assessment activities, at the same time, commercial banks should also play a role of propaganda and education, assist consumers and enterprises timely detection of carbon value and the value of derivatives, in order to play the role of bank support, and actively explore the public welfare publicity, marketing and charitable activities, the concept of low carbon products, services, and social welfare, etc. together, and client partner, to increase communication channels, enhance the low-carbon responsibility of citizens and enterprises.

\section{Conclusion}

Along with the low carbon economy era, to promote China's economic sustainable development.China's commercial banks in the initial stage, we need to continue to improve the relevant policies and regulations, strengthen the carbon finance product innovation, control carbon finance risk, cultivate high quality synthetic carbon finance talents, and strengthen cooperation with international financial institutions to promote the rapid development of China's commercial banks.

\section{References}

[1] Zhang Cungang, Zhang Xiaoying. research on development present situation, prospect and Countermeasure of "Carbon finance". Gansu theory research, 2010 (04)

[2] Gong Jun, Chen Lei. The innovation of carbon finance in commercial banks under the low carbon economy. Journal of Shandong University of Finance, 2011 (03)

[3] Chen tour. Carbon finance and Commercial Bank Business Innovation of China. Financial Forum (10, 2009)

[4] Situ Qiuling, Xu Ye. Thinking about the involvement of commercial banks in carbon finance market,. China new technology and new products, 2010 (03)

[5] Zhang Dalong. Carbon finance business development strategy of commercial banks in China. China real estate finance, 2011 (03)

[6] Chang Ying, Du Chunjing, Changchun commercial bank carbon finance business development practice strategy. value engineering, 2012 (22)

[7] Shu Xiang. Analysis of the opportunities and challenges faced by commercial banks in the low carbon economy era. financial economy, 2011 (20) 